\title{
Prognostic role of cyclin B1 in solid tumors: a meta-analysis
}

\author{
Chenyang $\mathrm{Ye}^{1, *}$, Ji Wang ${ }^{3, *}$, Pin Wu${ }^{2}$, Xiaofen $\mathrm{Li}^{1}$, Ying Chai ${ }^{2}$ \\ ${ }^{1}$ Cancer Institute (Key Laboratory of Cancer Prevention and Intervention, National Ministry of Education, Provincial Key \\ Laboratory of Molecular Biology in Medical Sciences), Second Affiliated Hospital, College of Medicine, Zhejiang University, \\ Hangzhou 310009, China \\ ${ }^{2}$ Department of Thoracic Surgery, Second Affiliated Hospital, College of Medicine, Zhejiang University, Hangzhou 310009, China \\ ${ }^{3}$ Department of Surgical Oncology, Sir Run Run Shaw Hospital, College of Medicine, Zhejiang University, Hangzhou 310016, China \\ *These authors contributed equally to this work
}

Correspondence to: Ying Chai, email: chaiy@126.com

Keywords: cyclin B1, solid tumors, prognosis, overall survival, meta-analysis

Received: October 07, $2016 \quad$ Accepted: November 16, $2016 \quad$ Published: November 26, 2016

\section{ABSTRACT}

Cyclin B1 is a key mitotic cyclin in the G2-M phase transition of the cell cycle and is overexpressed in various malignant tumors. Numerous studies have reported contradictory evidences of the correlation between cyclin B1 expression and prognosis in human solid tumors. To address this discrepancy, we conducted a metaanalysis with 17 published studies searched from PubMed and Medline. Cyclin B1 overexpression was significantly associated with poor 3-year overall survival (OS) $(O R=2.05,95 \% C I=1.20$ to $3.50, P=0.009)$ and 5 -year $O S(O R=2.11,95 \% C I=1.33$ to 3.36, $P=\mathbf{0 . 0 0 2}$ ) of solid tumors. Subgroup analysis revealed that elevated cyclin B1 expression was associated with worse prognosis of lung cancer and esophageal cancer but better prognosis of colorectal cancer. In summary, overexpression of cyclin B1 is correlated with poor survival in most solid tumors, which suggests that the expression status of cyclin B1 is a significant prognostic parameter in solid tumors.

\section{INTRODUCTION}

It is universally acknowledged that dysregulation of the cell cycle is closely correlated with proliferation of cancer cells, and is a hallmark of human carcinomas [1]. Progression of cell cycle is mediated by a series of cyclindependent kinases (cdks) and cyclins. Cyclins play vital roles at various phases of the cell cycle by activating specific cdks. Among various cyclin/cdk complexes regulating the cell cycle, cyclin $\mathrm{B} 1 / \mathrm{Cdc} 2$ is a widely studied complex, which controls $\mathrm{G}_{2}-\mathrm{M}$ phase checkpoint surveillance, and is essential for initiation of mitosis [2]. Cyclin B1, encoded by the CCNB1 gene [3], has been demonstrated to play a pivotal role in tumorigenesis and tumor development. In normal conditions, expression level of cyclin B1 is very low and increases sharply only at the G2-M phase transition. Deregulation of cyclin B1 can result in unrestricted cell-cycle progression and malignant transformation [4-7]. Overexpression of cyclin B1 has been reported in various human cancers, including breast [8], colorectal [9], lung [10], prostate [11], pancreatic [12], laryngeal [13], esophageal [14], gastric [15] and hepatocellular [16] cancers. A plenty of studies revealed that cyclin B1 is implicated in the differentiation, growth, apoptosis, metastasis and chemoresistance of cancer cell [14, 17-20]. Given the promoting role of cyclin B1 in tumor development, cyclin B1-targeted prevention and therapy might be beneficial. However, the prognostic merit of cyclin B1 overexpression in various solid tumors is still disputed.

A large number of studies demonstrated that enhanced expression of cyclin B1 in tumor tissue was associated with poor survival of patients with various types of solid tumors such as breast cancer [21, 22], lung cancer [10, 23-25], esophageal cancer [26-28], gastric cancer [15], hepatocellular carcinoma [16], pancreatic cancer [12, 29], embryonal tumors [30], and laryngeal carcinoma [13]. However, other studies revealed that overexpression of cyclin B1 was correlated with favorable outcome of patients with gastric cancer [15] and colorectal cancer [9, 31, 32].

Therefore, we conducted a meta-analysis to assess the prognostic value of cyclin B1 overexpression in human solid tumors. The purpose of this meta-analysis was to evaluate the relevance of elevated cyclin B1 expression with survival in solid tumors, and shed more light on the clinical merit of cyclin B1 as a therapeutic target and prognostic biomarker for solid tumors. 


\section{RESULTS}

\section{Search results and study characteristics}

17 studies with a total of 2492 patients were included (Figure 1). Characteristics of included studies were shown in Table 1. Four studies evaluated lung cancer [10, 23-25], three evaluated esophageal cancer [26-28], three evaluated colorectal cancer [9, 31, 32], two evaluated gastric cancer [15,33], and one each evaluated breast cancer [21], hepatocellular carcinoma [16], pancreatic cancer [12], laryngeal squamous cell carcinoma [13] and pediatric embryonal tumors [30]. All these 17 studies evaluated cyclin B1. As for the region, 12 studies were conducted in Asia, 2 studies in America, 2 studies in Europe, and 1 study in Austria.

\section{Evaluation and expression of cyclin B1}

A depiction of antibodies, detection and definition method, and cut-off values of cyclin B1 used in the included studies was presented in Table 2. Different antibodies were used for the appraisement of cyclin B1 expression by IHC. For anti-cyclin B1 antibody, four studies used clone $\mathrm{H}-433$, three studies used clone 7A9, two studies used clone V152, and eight studies did not report the antibody clone. Among the groups identified as cyclin B1 positive, the median expression of cyclin B1 in solid tumors was $48.78 \%$, range from $16.46 \%$ to $86.96 \%$.

\section{Association of cyclin B1 with survival}

A total of 15 studies reported data for OS at 3-years. Results showed that cyclin B1 overexpression was associated with worse 3-year $\mathrm{OS}$ of solid tumors $(\mathrm{OR}=2.05$, $95 \% \mathrm{CI}=1.20$ to $3.50, P=0.009$ ) (Figure 2). There was significant heterogeneity among studies (Cochran's Q $P<0.00001, I^{2}=74 \%$ ), so we conducted subgroup metaanalysis to explore whether the heterogeneity was due to different cancer types. 4 studies provided 3 -year OS for lung cancer, 3 for esophageal cancer and 3 for colorectal cancer. In the stratified analysis by cancer types, cyclin B1 overexpression was associated with worse 3-year $\mathrm{OS}$ of lung cancer $(\mathrm{OR}=2.95,95 \% \mathrm{CI}=1.64$ to 5.30 , $P=0.0003$ ) (Figure 3A), and esophageal cancer (OR $=4.95$, $95 \% \mathrm{CI}=2.58$ to $9.50, P<0.00001$ ) (Figure $3 \mathrm{~B}$ ). However, there was no association between cyclin $\mathrm{B} 1$ overexpression and 3-year OS of colorectal cancer (OR $=0.48,95 \%$ $\mathrm{CI}=0.21$ to $1.14, P=0.10)$ (Figure $\mathrm{S} 1)$.

A total of 15 studies reported data for OS at 5-years. Similar to the 3-year OS data, cyclin B1 overexpression was significantly associated with worse 5-year OS of solid tumors $(\mathrm{OR}=2.11,95 \% \mathrm{CI}=1.33$ to $3.36, P=0.002)$ (Figure 4). There was also high heterogeneity among studies (Cochran's Q $P<0.00001, I^{2}=77 \%$ ), so we performed subgroup meta-analysis according to different cancer types. 4 studies provided 5-year OS for lung cancer, 3 studies for esophageal cancer, 2 for colorectal cancer and 2 for gastric cancer. cyclin B1 overexpression was correlated with worse 5-year OS of lung cancer $(\mathrm{OR}=2.60,95 \% \mathrm{CI}=1.47$ to $4.60, P=0.0010)$ (Figure 5A) and esophageal cancer $(\mathrm{OR}=5.17,95 \%$ $\mathrm{CI}=2.83$ to $9.44, P<0.00001$ ) (Figure 5B). Interestingly, cyclin $\mathrm{B} 1$ overexpression was linked to favorable 5-year OS of colorectal cancer (OR $=0.49,95 \% \mathrm{CI}=0.30$ to $0.82, P=0.006$ ) (Figure $5 \mathrm{C}$ ). In addition, there was no association between cyclin B1 overexpression and 5-year $\mathrm{OS}$ of gastric cancer $(\mathrm{OR}=0.72,95 \% \mathrm{CI}=0.05$ to 11.51 , $P=0.82$ ) (Figure $\mathrm{S} 2$ ).

In addition, analysis of 4 studies revealed that there was no association between cyclin B1 overexpression and 10-year OS $(\mathrm{OR}=0.97,95 \% \mathrm{CI}=0.35$ to 2.69 , $P=0.96$ ) (Figure S3). And meta-analysis of the included studies indicated that expression of cyclin B1 was not significantly associated with 3-year (disease-free survival) DFS (OR $=2.32,95 \% \mathrm{CI}=0.90$ to $6.00, P=0.08)$ (Figure S4A) and 5-year DFS (OR $=1.42,95 \% \mathrm{CI}=0.69$ to $2.90, P=0.34$ ) (Figure $\mathrm{S} 4 \mathrm{~B}$ ). We also assessed the relationship between cyclin $\mathrm{B} 1$ overexpression and the TNM stage of solid tumors. The expression level of cyclin B1 was not significantly correlated with TNM stage $(\mathrm{OR}=0.51,95 \% \mathrm{CI}=0.25$ to $1.03, \mathrm{P}=0.06)($ Figure $\mathrm{S} 5)$.

Meta-regression analysis showed that publication year, country, age, gender, and NOS score did not contribute to the heterogeneity (data not shown).

\section{Sensitivity analyses}

Removal of the studies that was an outlier (IRS or IHC $<5 \%$ ) or no report (NR) with regard to the cutoff of cyclin B1 overexpression by IHC did not affect results for 3- or 5-year OS (OR $=2.24,95 \% \mathrm{CI}=1.25$ to $4.02, p<0.007$; OR $=2.31,95 \% \mathrm{CI}=1.47$ to 3.64 , $P=0.0003$; respectively). Exclusion of these studies did not substantially reduce heterogeneity for 3- or 5-year OS (Cochran's Q $P<0.00001, I^{2}=74 \%$; Cochran's Q $P<0.00001, \mathrm{I}^{2}=69 \%$, respectively).

Removal of the studies that patients received adjuvant therapy such as chemotherapy or radiotherapy after curative operation did not influence results for 3 - or 5-year $\mathrm{OS}(\mathrm{OR}=2.11,95 \% \mathrm{CI}=1.13$ to 3.96 , $p=0.02 ; \mathrm{OR}=2.40,95 \% \mathrm{CI}=1.42$ to $4.04, p=0.001$, respectively). Moreover, exclusion of these studies did not reduce heterogeneity for 3- or 5-year OS (Cochran's Q $P<0.00001, I^{2}=76 \%$; Cochran's Q $P<0.00001$, $I^{2}=76 \%$, respectively).

Removal of studies with NOS score 6 did not influence results for 3- or 5-year OS (OR $=1.94,95 \% \mathrm{CI}=1.12$ to $3.36, p=0.02 ; \mathrm{OR}=1.98,95 \% \mathrm{CI}=1.15$ to $3.40, p=0.01$, respectively). Exclusion of these studies did not reduce heterogeneity for 3- or 5-year OS (Cochran's Q $P<0.00001$, $I^{2}=76 \%$; Cochran's Q $P<0.00001, P=79 \%$, respectively). 


\section{Publication bias}

Funnel plot analysis indicated that there was no statistical evidence of publication bias in our meta-analysis (data not shown).

\section{DISCUSSION}

In previous cancer studies, overexpression of cyclin B1 was demonstrated to correlate with adverse survival outcome, while some others showed cyclin B1 was a potential biomarker for favorable prognosis. Here we conducted the first systematic evaluation of the literatures with respect to cyclin B1 expression and clinical outcomes in cancer patients to date. We thoroughly assessed survival data of 2492 solid tumor patients in 17 different studies and proved that the expression of cyclin B1 was a prognostic marker of unfavorable clinical outcome, with consistent results of OS at 3- and 5-years. Among the tumor types evaluated, elevated expression of cyclin B1 in tumor tissues was related with worse 3- and 5-year OS of lung cancer and esophageal carcinoma. However, elevated expression of cyclin B1 was associated with better 5-year OS of colorectal cancer. Our study also found there was no significant correlation between cyclin B1 overexpression and OS of gastric cancer. One study reported that cyclin B1 overexpression in gastric cancer tissues was associated with favorable OS, while recent research demonstrated that elevated cyclin B1 expression was correlated with reduced survival. These discrepancies suggest that further studies are warranted to elucidate the underling mechanism and role of cyclin B1 in pathogenesis and prognostic value in different tumor types.

Cyclin B1 is a pivotal mitotic cyclin in the $\mathrm{G} 2$ and $\mathrm{M}$ phases during the cell cycle [2,34]. It complexes with the active form of $\mathrm{Cdc} 2$ to initiate chromosome condensation, breakdown of the nuclear envelope, and assembly of the mitotic spindle [10]. Recent study reported that cyclin B1/Cdc2 phosphorylates and activates the mRNA cap RNMT (RNA guanine-7 methyltransferase) regulatory domain on $\mathrm{T} 77$ in $\mathrm{G} 2 / \mathrm{M}$ phase of the cell cycle, promoting the capping activity following mitosis [35]. A growing body of research indicates that dysregulated expression of cyclin B1 is a common event in cancer cells. Binding of Cdc2 can result in phosphorylation of other substrates at inappropriate times and uncontrolled proliferation, due to the inactivation of the tumor suppressor p53 $[4,36]$. Downregulation of cyclin $\mathrm{B} 1 / \mathrm{Cdc} 2$ reactivates and

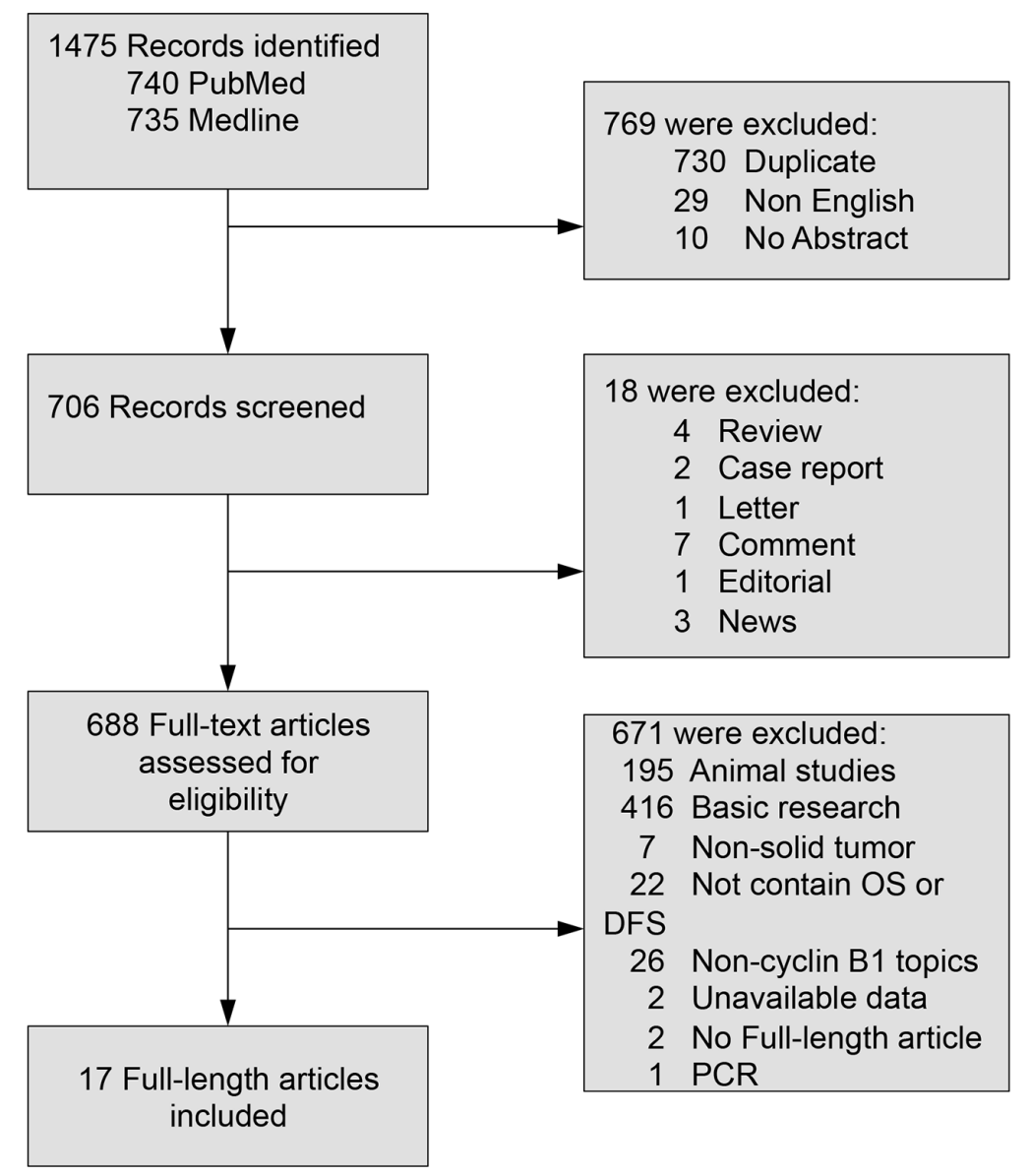

Figure 1: Flow diagram of the meta-analysis process. OS: overall survival; DFS: disease-free survival. 
Table 1: Characteristics of studies included in the meta-analysis

\begin{tabular}{|c|c|c|c|c|c|c|c|c|c|c|c|}
\hline References & Country & $\begin{array}{l}\text { Type of } \\
\text { cancer }\end{array}$ & $\begin{array}{l}\text { Patient } \\
\text { No. }\end{array}$ & $\begin{array}{l}\text { Age,median } \\
\text { (range) }\end{array}$ & Male/ Female & Stage & $\begin{array}{c}\text { Follow up, } \\
\text { months (Range) }\end{array}$ & $\begin{array}{l}\text { Cyclin B1 } \\
(+/-) \text { NO. }\end{array}$ & $\begin{array}{c}\text { 3-year } \\
\text { OS (+/-)\% }\end{array}$ & $\begin{array}{c}\text { 5-year } \\
\text { OS (+l-)\% }\end{array}$ & $\begin{array}{l}\text { NOS } \\
\text { Score }\end{array}$ \\
\hline Arinaga, M., et al. (2003) & Japan & NSCLC & 174 & $65(35-84)$ & $127 / 47$ & I-III & $54.6(1.4-134.6)$ & $74 / 100$ & $57.44 / 70.91$ & $48.48 / 59.05$ & 7 \\
\hline Begnami, M. D., et al. (2010) & Brazil & $\mathrm{GC}$ & 482 & $64(26-84)$ & $308 / 174$ & NR & $28.3(0.6-108.6)$ & $229 / 231$ & NR & $22.6 / 40$ & 6 \\
\hline Cooper, W. A., et al. (2009) & Australia & NSCLC & 90 & $67(41-78)$ & $58 / 32$ & I-II & $68.9(1-86.7)$ & $52 / 36$ & $55.89 / 81.82$ & $44.37 / 75.02$ & 7 \\
\hline Dong, Y., et al. (2002) & Japan & $\mathrm{LC}$ & 102 & $63.49(38-89)$ & $86 / 16$ & I-IV & $44.85(3-60)$ & $40 / 62$ & $54.75 / 73.55$ & $54.72 / 72.13$ & 8 \\
\hline Fang, Y., et al. (2015) & China & $\mathrm{CRC}$ & 150 & NR & $88 / 62$ & I-IV & NR & $88 / 62$ & $77.31 / 64.51$ & $65.27 / 39.83$ & 7 \\
\hline Grabsch, H., et al. (2004) & Germany & $\mathrm{CRC}$ & 342 & $68.8(28-88)$ & $149 / 181$ & I-IV & $50.4(5-136.8)$ & $261 / 69$ & $79.71 / 75.23$ & $72.67 / 61.65$ & 7 \\
\hline Huang, T., et al. (2014) & China & $\mathrm{EC}$ & 105 & $58.3(31-83)$ & $65 / 40$ & I-III & NR & $28 / 17$ & $67.79 / 93.68$ & $50.87 / 87.48$ & 6 \\
\hline Kim, D.-H. (2007) & Korea & $\mathrm{GC}$ & 23 & $57.1(29-77)$ & $15 / 8$ & I-IV & $68(3-108)$ & $20 / 3$ & $88.31 / 40.11$ & $82.25 / 40.11$ & 7 \\
\hline Li, J.-Q., et al. (2003) & Japan & $\mathrm{CRC}$ & 194 & NR & $104 / 90$ & I-IV & NR & $68 / 75$ & $99.02 / 82.94$ & NR & 7 \\
\hline Moschovi, M., et al. (2011) & Greece & PET & 53 & NR & $28 / 25$ & NR & NR & $26 / 16$ & $55.73 / 84.34$ & $55.74 / 84.34$ & 7 \\
\hline Nozoe, T., et al. (2002) & Japan & $\mathrm{EC}$ & 120 & $65(36-89)$ & $101 / 19$ & I-III & NR & $68 / 52$ & $61.6 / 85.51$ & $50.7 / 78.55$ & 7 \\
\hline Soria, J. C., et al. (2000) & USA & NSCLC & 77 & 65 & $54 / 23$ & I & 98.4 & $17 / 60$ & $41.03 / 73.37$ & $29.16 / 59.79$ & 8 \\
\hline Suzuki, T., et al. (2007) & Japan & $\mathrm{BC}$ & 109 & $53.1(23-82)$ & $0 / 109$ & I-III & $106(4-157)$ & $46 / 63$ & $91.67 / 100$ & $80.15 / 90.14$ & 8 \\
\hline Takeno, S., et al. (2002) & Japan & $\mathrm{EC}$ & 71 & $63.8(43-84)$ & $63 / 8$ & I-IV & NR & $35 / 36$ & $28.14 / 74.44$ & $21.57 / 68.99$ & 7 \\
\hline Weng, L., et al. (2012) & China & $\mathrm{HC}$ & 80 & NR & $70 / 10$ & $\begin{array}{l}\text { BCLC } \\
\text { stage A }\end{array}$ & 39.0 & $31 / 49$ & I & I & 6 \\
\hline Yoshida, T., et al. (2004) & Japan & NSCLC & 79 & NR & $54 / 25$ & I-III & NR & $13 / 66$ & $62.82 / 91.87$ & $62.82 / 84.99$ & 7 \\
\hline Zhou, L., et al. (2014) & China & $\mathrm{PC}$ & 241 & $60(34-85)$ & $159 / 82$ & NR & $13(2-87)$ & $175 / 66$ & $22.61 / 41.21$ & $17.29 / 33.91$ & 7 \\
\hline
\end{tabular}

NSCLC: Non-Small Cell Lung Cancer; GC: Gastric Cancer; CRC: Colorectal Cancer; BC: Breast Cancer; PC: Pancreatic Cancer; HC: Hepatocellular Carcinoma; EC: Esophageal Cancer; OSCC: LC: Laryngeal Carcinoma; PET: Pediatric Embryonal Tumors; NR: Not Reported; NOS: Newcastle-Ottawa Scale; OS: Overall Survival.

Table 2: Evaluation of human cyclin B1 by IHC in the selected studies

\begin{tabular}{|c|c|c|c|}
\hline References & $\begin{array}{l}\text { Type of } \\
\text { cancer }\end{array}$ & Cutoff & Antibody (Clone) \\
\hline Arinaga, M., et al. (2003) & NSCLC & $\mathrm{IHC}>10 \%$ & $\begin{array}{l}\text { anti-cyclin B1;monoclonal antibody (NR); } \\
\text { Novocastra }\end{array}$ \\
\hline Begnami, M. D., et al. (2010) & $\mathrm{GC}$ & $\mathrm{IHC}>10 \%$ & anti-cyclin B1(V152); DAKO \\
\hline Cooper, W. A., et al. (2009) & NSCLC & $\mathrm{IHC} \geq 5 \%$ & $\begin{array}{l}\text { anti-cyclin B1(7A9); monoclonal antibody; } \\
\text { Novocastra }\end{array}$ \\
\hline Dong, Y., et al. (2002) & $\mathrm{LC}$ & $\mathrm{IHC}>15 \%$ & Anti-cyclin B1 (H-433) polyclonal antibody; Santa Cruz \\
\hline Fang, Y., et al. (2015) & $\mathrm{CRC}$ & expression ratio $>3.33$ & NR \\
\hline Grabsch, H., et al. (2004) & $\mathrm{CRC}$ & $\mathrm{IHC}>10 \%$ & $\begin{array}{l}\text { anti-cyclin B1(7A9); monoclonal antibody; } \\
\text { Novocastra }\end{array}$ \\
\hline Huang, T., et al. (2014) & $\mathrm{EC}$ & IHC score 5-6 & anti-cyclin B1(H433); polyclonal antibody; Santa Cruz \\
\hline Kim, D.-H. (2007) & $\mathrm{GC}$ & $\mathrm{IHC}>5 \%$ & anti-cyclin B1; (NR);Novocastra \\
\hline Li, J.-Q., et al. (2003) & $\mathrm{CRC}$ & $\mathrm{IHC} \geq 4.6 \%$ & anti-cyclin B1(H-433); Santa Cruz \\
\hline Moschovi, M., et al. (2011) & PET & $\mathrm{IHC}>15 \%$ & anti-cyclin B1(7A9); Novocastra \\
\hline Nozoe, T., et al. (2002) & $\mathrm{EC}$ & $\mathrm{IHC}>10 \%$ & $\begin{array}{l}\text { anti-cyclin B1;monoclonal antibody } \\
\text { (NR);Novocastra }\end{array}$ \\
\hline Soria, J. C., et al. (2000) & NSCLC & $\mathrm{IHC} \geq 15 \%$ & $\begin{array}{l}\text { anti-cyclin B1; monoclonal antibody } \\
\text { (NR);Novocastra }\end{array}$ \\
\hline Suzuki, T., et al. (2007) & $\mathrm{BC}$ & $\mathrm{IHC}>10 \%$ & anti-cyclin B1(H-433); polyclonal antibody;Santa Cruz \\
\hline Takeno, S., et al. (2002) & $\mathrm{EC}$ & $\mathrm{IHC}>20 \%$ & $\begin{array}{l}\text { anti-cyclin B1; monoclonal antibody } \\
\text { (NR);Novocastra }\end{array}$ \\
\hline Weng, L., et al. (2012) & $\mathrm{HC}$ & NR & $\begin{array}{l}\text { anti-cyclin B1 (V152); monoclonal antibody ;Cell } \\
\text { Signaling Technology }\end{array}$ \\
\hline Yoshida, T., et al. (2004) & NSCLC & $\mathrm{IHC}>15 \%$ & $\begin{array}{l}\text { anti-Cyclin B1; monoclonal antibody; } \\
\text { (NR);Novocastra }\end{array}$ \\
\hline Zhou, L., et al. (2014) & $\mathrm{PC}$ & IHC grade 2 & anti-cyclin B1; monoclonal; Abcam \\
\hline
\end{tabular}

NSCLC: Non-Small Cell Lung Cancer; GC: Gastric Cancer; CRC: Colorectal Cancer; BC: Breast Cancer; PC: Pancreatic Cancer; HC: Hepatocellular.

Carcinoma; EC: Esophageal Cancer; OSCC: LC: Laryngeal Carcinoma; PET: Pediatric Embryonal Tumors; NR: Not Reported. 
stabilizes the function of p53 in cancer cells [37, 38]. Accoding to previous data, altered expression of cyclin B1 has been detected in a large variety of solid tumors, and gets involved in cells growth, apoptosis and metastasis. Interestingly, studies also revealed that abnormally expressed cyclin B1 could be discerned by the immune system as tumor antigens in early stages of cancer, which is possible to be used for early cancer detection by monitoring the immune responses. [39-41]. Apart from being a promising biomarker, cyclin B1 may also provide

\begin{tabular}{|c|c|c|c|c|c|c|c|c|c|c|}
\hline \multirow[b]{2}{*}{ Study or Subgroup } & \multicolumn{2}{|c|}{ cyclin B1(-) } & \multicolumn{2}{|c|}{ cyclin B1(+) } & \multirow[b]{2}{*}{ Weight } & \multirow{2}{*}{$\begin{array}{c}\text { Odds Ratio } \\
\text { M-H, Random, } 95 \% \mathrm{Cl}\end{array}$} & \multirow{2}{*}{\multicolumn{3}{|c|}{$\begin{array}{c}\text { Odds Ratio } \\
\text { M-H, Random. } 95 \% \mathrm{Cl}\end{array}$}} & \\
\hline & Events & Total & Events & Total & & & & & & \\
\hline Arinaga, M., et al. (2003) & 71 & 100 & 43 & 74 & $9.1 \%$ & $1.77[0.94,3.32]$ & & & & \\
\hline Cooper, W. A., et al. (2009) & 29 & 36 & 29 & 52 & $7.7 \%$ & $3.29[1.22,8.85]$ & & & & \\
\hline Dong, Y., et al. (2002) & 46 & 62 & 22 & 40 & $8.3 \%$ & $2.35[1.01,5.47]$ & & & & \\
\hline Fang, Y., et al. (2015) & 40 & 62 & 68 & 88 & $8.8 \%$ & $0.53[0.26,1.10]$ & & & & \\
\hline Grabsch, H., et al. (2004) & 52 & 69 & 208 & 261 & $9.2 \%$ & $0.78[0.42,1.46]$ & & & & \\
\hline Huang, T., et al. (2014) & 16 & 17 & 19 & 28 & $3.9 \%$ & $7.58[0.87,66.40]$ & & & & \\
\hline Kim, D.-H. (2007) & 1 & 3 & 18 & 20 & $2.7 \%$ & $0.06[0.00,0.92]$ & & & & \\
\hline Li, J.-Q., et al. (2003) & 62 & 75 & 67 & 68 & $4.1 \%$ & $0.07[0.01,0.56]$ & & & & \\
\hline Moschovi, M., et al. (2011) & 13 & 16 & 14 & 26 & $5.8 \%$ & $3.71[0.85,16.21]$ & & & & \\
\hline Nozoe, T., et al. (2002) & 44 & 52 & 42 & 68 & $8.1 \%$ & $3.40[1.39,8.36]$ & & & & \\
\hline Soria, J. C., et al. (2000) & 44 & 60 & 7 & 17 & $7.2 \%$ & $3.93[1.28,12.07]$ & & & & \\
\hline Suzuki, T., et al. (2007) & 63 & 63 & 42 & 46 & $2.5 \%$ & $13.45[0.71,256.26]$ & & & & \\
\hline Takeno, S., et al. (2002) & 27 & 36 & 10 & 35 & $7.5 \%$ & $7.50[2.62,21.48]$ & & & & \\
\hline Yoshida, T., et al. (2004) & 61 & 66 & 8 & 13 & $6.0 \%$ & $7.63[1.80,32.25]$ & & & & \\
\hline Zhou, L., et al. (2014) & 27 & 66 & 40 & 175 & $9.2 \%$ & $2.34[1.28,4.28]$ & & & & \\
\hline Total $(95 \% \mathrm{Cl})$ & & 783 & & 1011 & $100.0 \%$ & $2.05[1.20,3.50]$ & & & & \\
\hline Total events & 596 & & 637 & & & & & & & \\
\hline $\begin{array}{l}\text { Heterogeneity: } \operatorname{Tau}^{2}=0.72 \\
\text { Test for overall effect: } Z=2 \text {. }\end{array}$ & $\begin{array}{l}\mathrm{i}^{2}=54.9 \\
(\mathrm{P}=0.0\end{array}$ & , df = 1 & $4(P<0 . C$ & 0001); & $=74 \%$ & & 0.01 & $\begin{array}{l}0.1 \\
\text { cyclin B1(-) }\end{array}$ & $\begin{array}{l}10 \\
\text { cyclin B1(+) }\end{array}$ & 100 \\
\hline
\end{tabular}

Figure 2: The relationship between expression level of cyclin B1 and 3-year overall survival (OS) of all patients with solid tumors.

\section{A. Non-small-cell lung cancer}

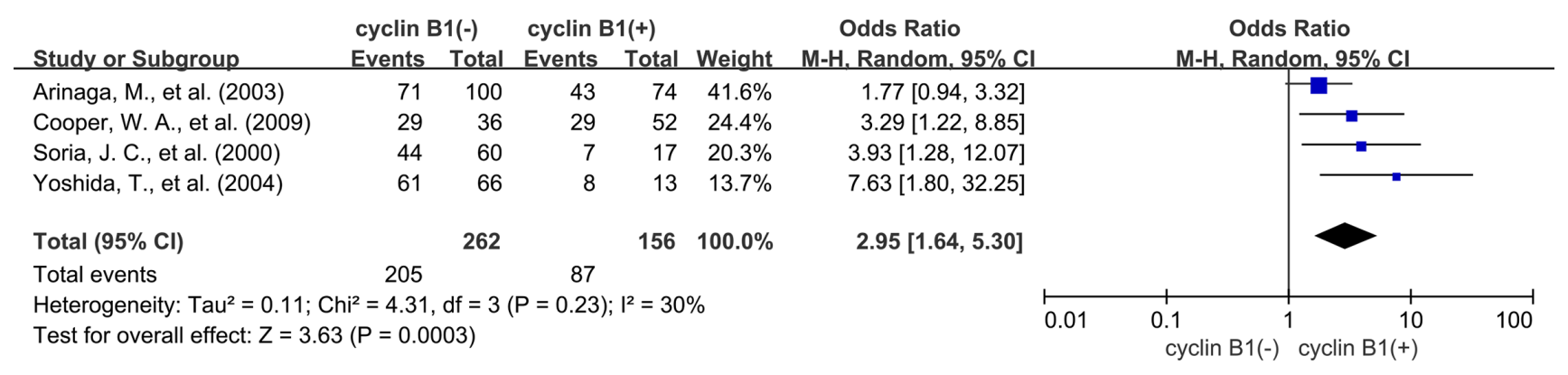

\section{B. Esophageal cancer}

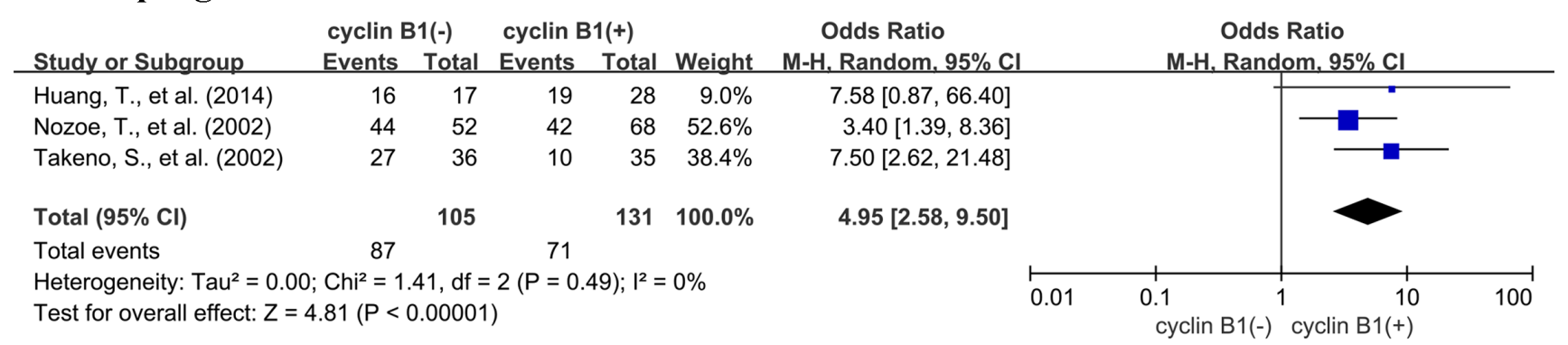

Figure 3: Subgroup analysis of 3-year OS by expression level of cyclin B1 in different cancer types. (A) non-small-cell lung cancer; (B) esophageal cancer. 


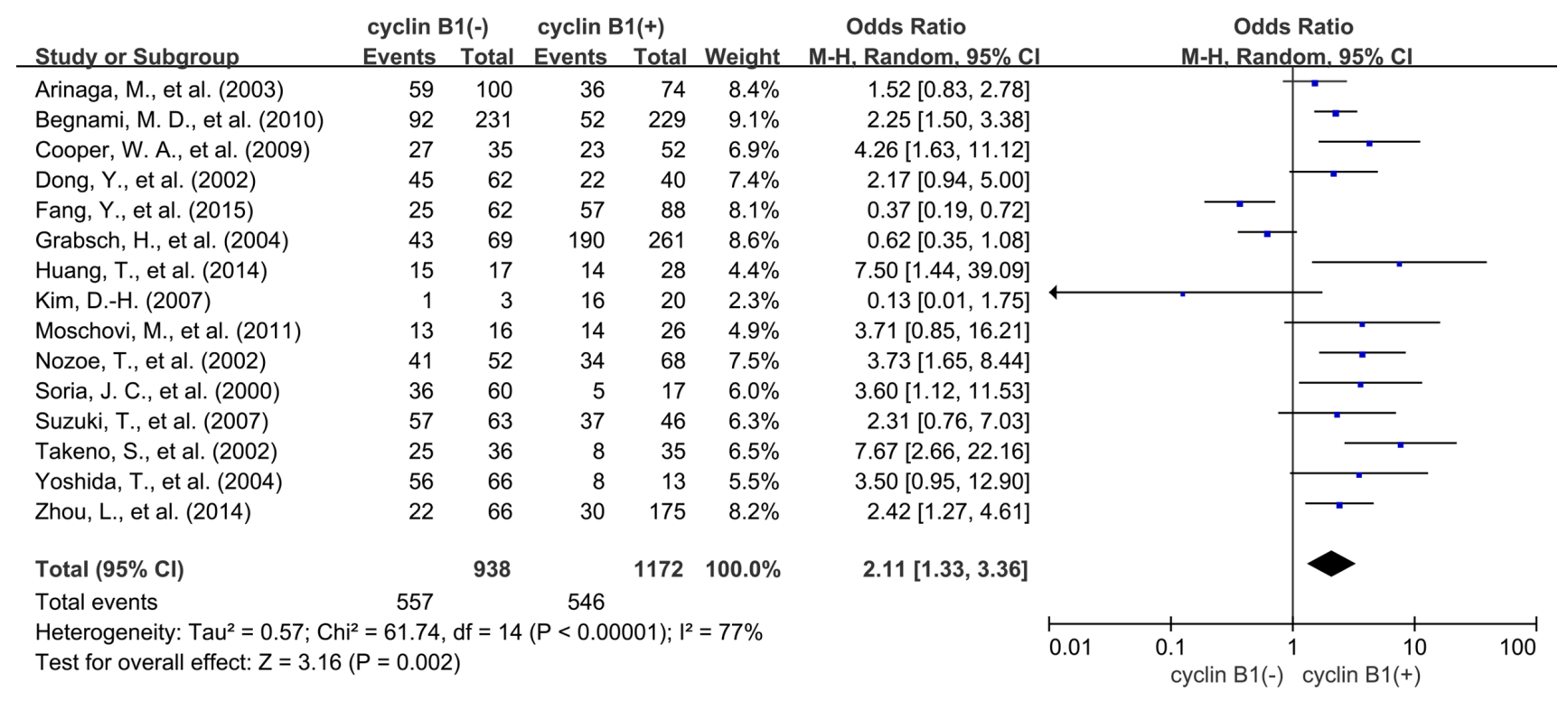

Figure 4: 5-year OS by cyclin B1 expression.

\section{A. Non-small-cell lung cancer}

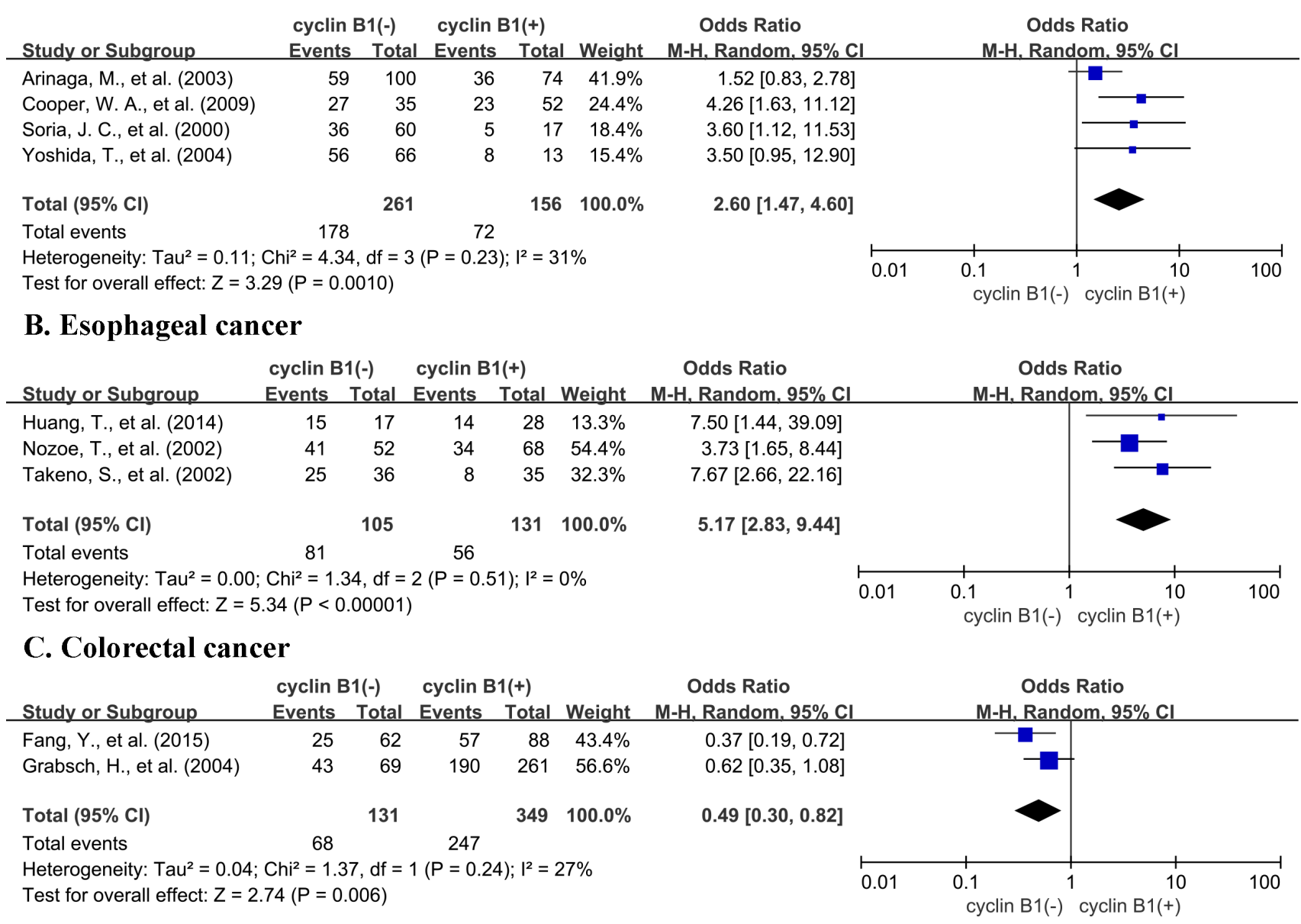

Figure 5: Subgroup analysis of 5-year OS by cyclin B1 expression in various tumor types. (A) non-small-cell lung cancer; (B) esophageal cancer; (C) colorectal cancer. 
a new target for anticancer therapy. One study showed that the diacerein resulted in the viability reduction of chondrosarcoma cells and G2/M cell cycle arrest by cyclin B1/ Cdc2 downregulation [42]. In RNA level, some research performed gene expression analysis by RT-PCR, and indicated that $C C N B 1$ was strongly correlated with disease recurrence in solid cancer. However, in the protein level, the association between elevated cyclin B1 and clinical prognosis in solid tumors remains controversial. In light of the important role of cyclin B1 in biology mechanism and clinical application, we performed this meta-analysis to evaluate the prognostic merit of cyclin B1 expression in solid tumors.

This meta-analysis study involves several pivotal implications. First, it reveals that cyclin B1 expression is correlated to unfavorable outcome of most solid tumors, which indicates that cyclin B1 may be a promising therapeutic target. Second, it identifies a subgroup of tumors with adverse outcome in lung cancer and esophageal carcinoma, but with favorable outcome in colorectal cancer. Finally, it highlights the potential clinical application of cyclin B1 as a valuable prognostic biomarker.

Several limitations also exist in this meta-analysis. First, some studies reporting negative results may not be published, which inevitably results in publication bias. Second, subgroup analysis for each type of cancer was not feasible in this meta-analysis because some types of cancer failed to contain enough data. Third, the method and cut-off values for evaluating cyclin B1 expression are nonuniform. Lastly, substantial heterogeneity observed among included studies cannot be completely interpreted in spite of the use of appropriate meta-analytic techniques with random-effects models.

In conclusion, our analysis indicates that cyclin $\mathrm{B} 1$ expression is associated with unfavorable outcome in most solid tumors, suggesting that cyclin B1 is a valuable prognostic indicator and a potential therapeutic target for solid tumors.

\section{MATERIALS AND METHODS}

This meta-analysis was carried out based on the Preferred Reporting Items for Systematic Reviews and Meta-Analyses (PRISMA) statement [43]. This study was on the basis of analysis and summary of the results of previous published studies; thus the ethical approval was not necessary.

\section{Search protocol}

We conducted a thorough search of Pubmed and Web of Science for studies evaluating expression of cyclin B1 and survival in cancer patients from 1995 to March 2016. The search terms "cyclin B1" and "neoplasms" were used and the results were restricted to human studies of solid tumors. A total of 740 and 735 entries were identified, respectively. Inclusion criteria were the measurement of cyclin B1 by immunohistochemistry (IHC), availability of survival data for at least 3 years, and publication in English. Studies evaluating gene expression of cyclin B1 measured by polymerase chain reaction were excluded. We checked the citation lists of retrieved articles to ensure sensitivity of the search strategy. Study selection was based on the association of cyclin B1 and survival. Inter-reviewer agreement was assessed using Cohen's kappa coefficient. Any disagreements between authors were resolved by consulting a third author until a final consensus was reached.

\section{Endpoints of interest}

The primary endpoints were overall survival (OS) at 3 and 5 years. Tumors were classified by cyclin B1 expression status using cut-offs as defined by each study.

\section{Data collection process and quality assessment}

The following details were independently extracted by two authors (CYY and JW): name of first author, publication year, country, type of cancer, number of patients, median age, gender, time of follow-up, antibody used for the evaluation, technique used to quantify cyclin $\mathrm{B} 1$, and cut-off value to determine cyclin B1 positivity. OS data were extracted from the tables or Kaplan-Meier curves for both cyclin B1 negative and cyclin B1 positive group. The studies included in this meta-analysis were all cohort studies. Two authors independently assessed the quality of each included study by Newcastle-Ottawa Scale (NOS) [44]. The studies with 6 scores or more were denoted as high quality studies. A consensus NOS score for each item was achieved by discussion.

\section{Data synthesis}

The relative frequency of OS at 3- and 5-year between cyclin B1 negative and cyclin B1 positive group was presented as an odds ratio (OR) and its 95\% confidence interval (CI). Sensitivity analyses were carried out for different analytical methods and cut-offs for defining cyclin B1 expression and NOS scores for quality assessment of included studies.

\section{Statistical analysis}

Data were extracted from the primary publications and analysed by RevMan 5.3 analysis software (Cochrane Collaboration, Copenhagen, Denmark). Estimates of ORs were weighted and pooled using the Mantel-Haenszel random effect model. Statistical heterogeneity was assessed with the Cochran's Q and $I^{2}$ statistics. Differences between subgroups were assessed using methods described in Cochrane Handbook for Systematic Reviews 
of Interventions [45]. Meta-regression analysis was carried out by Stata 12.0 software (StataCorp LP, College Station, TX). All statistical tests were two-sided, and statistical significance was defined as P less than 0.05 .

\section{ACKNOWLEDGMENTS AND FUNDING}

We thank all the group members for helpful discussions. This work was supported by grants from the National Natural Science Foundation of China (81572800, PW), the Science and Technology Department of Zhejiang Province (2013c03044-7, YC), and Natural Science Foundation of Zhejiang Province (LY13H160016, YC; LY15H160041, PW).

\section{CONFLICTS OF INTEREST}

The authors declare no competing financial interest.

\section{REFERENCES}

1. Sherr CJ. Cancer cell cycles. Science. 1996; 274:1672-1677.

2. Pines J, Hunter T. Human cyclin A is adenovirus E1Aassociated protein $\mathrm{p} 60$ and behaves differently from cyclin B. Nature. 1990; 346:760-763.

3. Sartor H, Ehlert F, Grzeschik KH, Muller R, Adolph S. Assignment of two human cell cycle genes, CDC25C and CCNB1, to 5q31 and 5q12, respectively. Genomics. 1992; 13:911-912.

4. Innocente SA, Abrahamson JL, Cogswell JP, Lee JM. p53 regulates a G2 checkpoint through cyclin B1. Proceedings of the National Academy of Sciences of the United States of America. 1999; 96:2147-2152.

5. Nimeus-Malmstrom E, Koliadi A, Ahlin C, Holmqvist M, Holmberg L, Amini RM, Jirstrom K, Warnberg F, Blomqvist C, Ferno M, Fjallskog ML. Cyclin B1 is a prognostic proliferation marker with a high reproducibility in a population-based lymph node negative breast cancer cohort. International Journal of Cancer. 2010; 127:961-967.

6. Ling CQ, Wang LN, Wang Y, Zhang YH, Yin ZF, Wang M, Ling $\mathrm{C}$. The roles of traditional Chinese medicine in gene therapy. Journal of Integrative Medicine. 2014; 12:67-75.

7. Zang QQ, Zhang L, Gao N, Huang C. Ophiopogonin D inhibits cell proliferation, causes cell cycle arrest at G2/M, and induces apoptosis in human breast carcinoma MCF-7 cells. Journal of Integrative Medicine. 2016; 14:51-59.

8. Agarwal R, Gonzalez-Angulo A-M, Myhre S, Carey M, Lee J-S, Overgaard J, Alsner J, Stemke-Hale K, Lluch A, Neve RM, Kuo WL, Sorlie T, Sahin A, et al. Integrative analysis of cyclin protein levels identifies cyclin b1 as a classifier and predictor of outcomes in breast cancer. Clinical Cancer Research. 2009; 15:3654-3662.

9. Li J-Q, Kubo A, Wu F, Usuki H, Fujita J, Bandoh S, Masaki T, Saoo K, Takeuchi H, Kobayashi S, Imaida K,
Maeta H, Ishida T, et al. Cyclin B1, unlike cyclin G1, increases significantly during colorectal carcinogenesis and during later metastasis to lymph nodes. International Journal of Oncology. 2003; 22:1101-1110.

10. Soria JC, Jang SJ, Khuri FR, Hassan K, Liu D, Hong WK, Mao L. Overexpression of cyclin B1 in early-stage nonsmall cell lung cancer and its clinical implication. Cancer Research. 2000; 60:4000-4004.

11. Mashal RD, Lester S, Corless C, Richie JP, Chandra R, Propert KJ, Dutta A. Expression of cell cycle-regulated proteins in prostate cancer. Cancer Research. 1996; 56:4159-4163.

12. Zhou L, Li J, Zhao Y-P, Cui Q-C, Zhou W-X, Guo J-C, You L, Wu W-M, Zhang T-P. The prognostic value of Cyclin B1 in pancreatic cancer. Medical Oncology (Northwood, London, England). 2014; 31:107.

13. Dong Y, Sui L, Watanabe Y, Sugimoto K, Tokuda M. Clinical relevance of cyclin B1 overexpression in laryngeal squamous cell carcinoma. Cancer Letters. 2002; 177:13-19.

14. Song Y, Zhao C, Dong L, Fu M, Xue L, Huang Z, Tong T, Zhou Z, Chen A, Yang Z, Lu N, Zhan Q. Overexpression of cyclin B1 in human esophageal squamous cell carcinoma cells induces tumor cell invasive growth and metastasis. Carcinogenesis. 2008; 29:307-315.

15. Begnami MD, Fregnani JHTG, Nonogaki S, Soares FA. Evaluation of cell cycle protein expression in gastric cancer: cyclin B1 expression and its prognostic implication. Human Pathology. 2010; 41:1120-1127.

16. Weng L, Du J, Zhou Q, Cheng B, Li J, Zhang D, Ling C. Identification of cyclin B1 and Sec62 as biomarkers for recurrence in patients with HBV-related hepatocellular carcinoma after surgical resection. Molecular Cancer. 2012; 11:39.

17. Matthess Y, Raab M, Sanhaji M, Lavrik IN, Strebhardt K. Cdk1/cyclin B1 controls Fas-mediated apoptosis by regulating caspase- 8 activity. Molecular and Cellular Biology. 2010; 30:5726-5740.

18. Kedinger V, Meulle A, Zounib O, Bonnet ME, Gossart JB, Benoit E, Messmer M, Shankaranarayanan P, Behr JP, Erbacher P, Bolcato-Bellemin AL. Sticky siRNAs targeting survivin and cyclin B1 exert an antitumoral effect on melanoma subcutaneous xenografts and lung metastases. BMC Cancer. 2013; 13:338.

19. Bonnet ME, Gossart JB, Benoit E, Messmer M, Zounib O, Moreau V, Behr JP, Lenne-Samuel N, Kedinger V, Meulle A, Erbacher P, Bolcato-Bellemin AL. Systemic delivery of sticky siRNAs targeting the cell cycle for lung tumor metastasis inhibition. Journal of Controlled Release. 2013; 170:183-190.

20. Gomez LA, de Las Pozas A, Reiner T, Burnstein K, PerezStable C. Increased expression of cyclin B1 sensitizes prostate cancer cells to apoptosis induced by chemotherapy. Molecular Cancer Therapeutics. 2007; 6:1534-1543.

21. Suzuki T, Urano T, Miki Y, Moriya T, Akahira J-i, Ishida T, Horie K, Inoue S, Sasano H. Nuclear cyclin B1 in human 
breast carcinoma as a potent prognostic factor. Cancer Science. 2007; 98:644-651.

22. Aaltonen K, Amini RM, Heikkila P, Aittomaki K, Tamminen A, Nevanlinna H, Blomqvist C. High cyclin B1 expression is associated with poor survival in breast cancer. British Journal of Cancer. 2009; 100:1055-1060.

23. Cooper WA, Kohonen-Corish MRJ, McCaughan B, Kennedy C, Sutherland RL, Lee CS. Expression and prognostic significance of cyclin B1 and cyclin A in nonsmall cell lung cancer. Histopathology. 2009; 55:28-36.

24. Arinaga M, Noguchi T, Takeno S, Chujo M, Miura T, Kimura Y, Uchida Y. Clinical implication of cyclin B1 in non-small cell lung cancer. Oncology Reports. 2003; 10:1381-1386.

25. Yoshida T, Tanaka S, Mogi A, Shitara Y, Kuwano H. The clinical significance of Cyclin B1 and Wee1 expression in non-small-cell lung cancer. Annals of Oncology. 2004; $15: 252-256$.

26. Takeno S, Noguchi T, Kikuchi R, Uchida Y, Yokoyama S, Muller W. Prognostic value of cyclin B1 in patients with esophageal squamous cell carcinoma. Cancer. 2002; 94:2874-2881.

27. Nozoe T, Korenaga D, Kabashima A, Ohga T, Saeki H, Sugimachi K. Significance of cyclin B1 expression as an independent prognostic indicator of patients with squamous cell carcinoma of the esophagus. Clinical Cancer Research. 2002; 8:817-822.

28. Huang T, Chen S, Han H, Li H, Huang Z, Zhang J, Yin Q, Wang X, Ma X, Dai P, Duan D, Zou F, Chen X. Expression of Hsp90alpha and cyclin B1 were related to prognosis of esophageal squamous cell carcinoma and keratin pearl formation. International Journal of Clinical and Experimental Pathology. 2014; 7:1544-1552.

29. Kamio Y, Maeda K, Moriya T, Takasu N, Takeshita A, Hirai I, Kimura W, Yamakawa M. Clinicopathological significance of cell cycle regulatory factors and differentiation-related factors in pancreatic neoplasms. Pancreas. 2010; 39:345-352.

30. Moschovi M, Alexiou GA, Patereli A, Stefanaki K, DoussisAnagnostopoulou I, Stofas A, Sfakianos G, Prodromou N. Prognostic significance of cyclin A and B1 in pediatric embryonal tumors. Journal of Neuro-Oncology. 2011; 103:699-704.

31. Grabsch H, Lickvers K, Hansen O, Takeno S, Willers R, Stock W, Gabbert HE, Mueller W. Prognostic value of cyclin B1 protein expression in colorectal cancer. American Journal of Clinical Pathology. 2004; 122:511-516.

32. Fang Y, Liang X, Jiang W, Li J, Xu J, Cai X. Cyclin b1 suppresses colorectal cancer invasion and metastasis by regulating e-cadherin. PloS One. 2015; 10:e0126875.

33. Kim D-H. Prognostic implications of cyclin B1, p34cdc2, p27(Kip1) and p53 expression in gastric cancer. Yonsei Medical Journal. 2007; 48:694-700.

34. Pines $\mathrm{J}$, Hunter $\mathrm{T}$. Isolation of a human cyclin cDNA: evidence for cyclin mRNA and protein regulation in the cell cycle and for interaction with p34cdc2. Cell. 1989; 58:833-846.
35. Aregger M, Kaskar A, Varshney D, Fernandez-Sanchez ME, Inesta-Vaquera FA, Weidlich S, Cowling VH. CDK1Cyclin B1 Activates RNMT, Coordinating mRNA Cap Methylation with G1 Phase Transcription. Molecular Cell. 2016; 61:734-746.

36. Yu M, Zhan Q, Finn OJ. Immune recognition of cyclin B1 as a tumor antigen is a result of its overexpression in human tumors that is caused by non-functional p53. Molecular Immunology. 2002; 38:981-987.

37. Schwermer M, Lee S, Koster J, van Maerken T, Stephan H, Eggert A, Morik K, Schulte JH, Schramm A. Sensitivity to cdk1-inhibition is modulated by p53 status in preclinical models of embryonal tumors. Oncotarget. 2015; 6:1542515435. doi: 10.18632/oncotarget.3908.

38. Kreis NN, Sanhaji M, Kramer A, Sommer K, Rodel F, Strebhardt K, Yuan J. Restoration of the tumor suppressor p53 by downregulating cyclin B1 in human papillomavirus 16/18-infected cancer cells. Oncogene. 2010; 29:5591-5603.

39. Egloff AM, Vella LA, Finn OJ. Cyclin B1 and other cyclins as tumor antigens in immunosurveillance and immunotherapy of cancer. Cancer Research. 2006; 66:6-9.

40. Pandey JP, Kistner-Griffin E, Namboodiri AM, Iwasaki M, Kasuga Y, Hamada GS and Tsugane S. Higher levels of antibodies to the tumour-associated antigen cyclin B1 in cancer-free individuals than in patients with breast cancer. Clinical and Experimental Immunology. 2014; 178:75-78.

41. Chevaleyre C, Benhamouda N, Favry E, Fabre E, Mhoumadi A, Nozach H, Marcon E, Cosler G, Vinatier E, Oudard S, Hans S, Le Pimpec-Barthes F, Bats AS, et al. The Tumor Antigen Cyclin B1 Hosts Multiple CD4 T Cell Epitopes Differently Recognized by Pre-Existing Naive and Memory Cells in Both Healthy and Cancer Donors. Journal of Immunology (Baltimore, Md : 1950). 2015; 195:1891-1901.

42. Lohberger B, Leithner A, Stuendl N, Kaltenegger H, Kullich W, Steinecker-Frohnwieser B. Diacerein retards cell growth of chondrosarcoma cells at the G2/M cell cycle checkpoint via cyclin B1/CDK1 and CDK2 downregulation. BMC Cancer. 2015; 15:891.

43. Liberati A, Altman DG, Tetzlaff J, Mulrow C, Gotzsche PC, Ioannidis JPA, Clarke M, Devereaux PJ, Kleijnen J, Moher D. The PRISMA Statement for Reporting Systematic Reviews and Meta-Analyses of Studies That Evaluate Health Care Interventions: Explanation and Elaboration. Plos Medicine. 2009; 6.

44. Stang A. Critical evaluation of the Newcastle-Ottawa scale for the assessment of the quality of nonrandomized studies in meta-analyses. European Journal of Epidemiology. 2010; 25:603-605.

45. Deeks JJ HJ, Altman DG. Analysing and presenting results. In: Higgins JPT, Green S, ed. Cochrane Handbook for Systematic Reviews of Interventions 425 Chichester, UK: John Wiley \& Sons. 2006. 